University of Nebraska - Lincoln

DigitalCommons@University of Nebraska - Lincoln

Agronomy \& Horticulture -- Faculty Publications

Agronomy and Horticulture Department

2019

Soil Fauna Accelerate Dung Pat Decomposition and Nutrient

Cycling into Grassland Soil

Kenneth S. Evans

Martha Mamo

Ana Wingeyer

Walter Schacht

Kent Eskridge

See next page for additional authors

Follow this and additional works at: https://digitalcommons.unl.edu/agronomyfacpub

Part of the Agricultural Science Commons, Agriculture Commons, Agronomy and Crop Sciences Commons, Botany Commons, Entomology Commons, Horticulture Commons, Other Plant Sciences

Commons, and the Plant Biology Commons

This Article is brought to you for free and open access by the Agronomy and Horticulture Department at DigitalCommons@University of Nebraska - Lincoln. It has been accepted for inclusion in Agronomy \& Horticulture -Faculty Publications by an authorized administrator of DigitalCommons@University of Nebraska - Lincoln. 
Authors

Kenneth S. Evans, Martha Mamo, Ana Wingeyer, Walter Schacht, Kent Eskridge, Jeff Bradshaw, and Daniel Ginting 


\title{
Soil Fauna Accelerate Dung Pat Decomposition and Nutrient Cycling into Grassland Soil
}

\author{
Kenneth S. Evans, ${ }^{1}$ Martha Mamo, ${ }^{1}$ Ana Wingeyer, ${ }^{2}$ \\ Walter H. Schacht, ${ }^{1}$ Kent M. Eskridge, ${ }^{3}$ Jeff Bradshaw, ${ }^{4}$ \\ and Daniel Ginting ${ }^{1}$
}

\begin{abstract}
1 Department of Agronomy and Horticulture, University of Nebraska, Lincoln, NE 68583-0915, USA

2 Instituto Nacional de Tecnología Agropecuaria, Oro Verde Entre Ríos, Argentina

3 Department of Statistics, University of Nebraska, Lincoln, NE 68583-0963, USA

4 Department of Entomology, Panhandle Research and Extension Center,

University of Nebraska, Scottsbluff, NE 69361, USA

Corresponding author - Martha Mamo, Department of Agronomy and Horticulture, University of Nebraska-Lincoln, 202 Keim Hall, Lincoln, NE 68583-0915, USA. emailmmamo3@unl.edu
\end{abstract}

\begin{abstract}
Soil fauna play critical roles in various ecosystem functions and services, but empirical data measuring their impact on dung pat decomposition and subsequent nutrient cycling into rangeland soils are limited. The objective of this study was to quantify the effect of soil fauna, using dung beetle as an indicator, on dung decomposition and subsequent translocation of dung nutrients into grassland soil over time. A field experiment was conducted early in the summer season and late in the summer season of 2014 and 2015. In each season, dung beetle abundance, changes in dung properties, and subsequent translocation of dung nutrients into soils were evaluated at 1,3 ,
\end{abstract}

Published in Rangeland Ecology \& Management 72 (2019) 667-677

doi 10.1016/j.rama.2019.01.008

Copyright (C) 2019; published by Elsevier Inc. on behalf of The Society for Range Management. Used by permission.

Submitted 27 August 2018; revised 29 January 2019; accepted 31 January 2019.

The project was supported by the Agriculture and Food Research Initiative Competitive Grant Program (2013-67019-21394) from the U.S. Department of Agriculture National Institute of Food and Agriculture and the University of Nebraska-Lincoln Agricultural Research Division. 
$7,14,28$, and $56 \mathrm{~d}$ after placement (DAPs) of exposed dung and nonexposed dung to beetles. Analysis of no-dung control soil was included for comparison. Dung beetles contributed $7 \%$ and $4 \%$ in the losses of dung moisture and dry matter (DM), respectively; however, dung beetles had no effect on dung pat nutrients. Losses of dung nutrients- $42 \%$ of water-extractable organic carbon, $46 \%$ of water-extractable phosphorus, and $65 \%$ of $\mathrm{NH}_{4}$ - occurred during the first 14 DAPs. Dung beetles increased soil nutrients in the top 10-cm depth beneath the dung. No effect of beetles was observed in deeper $(>10-\mathrm{cm})$ soil depth or in soil $30 \mathrm{~cm}$ away from the dung. This study concluded that soil fauna, such as dung beetles, accelerated dung moisture and DM losses and subsequent nutrient increase into the top $10 \mathrm{~cm}$ of soil.

Keywords: dung beetle, dung decomposition, nutrient cycling, rangelands,

\section{Introduction}

Soil fauna play critical roles in various ecosystem functions and services, but empirical data measuring their effects on dung decomposition and nutrient cycling in rangelands are limited. One of several ecosystem services provided by soil fauna is the acceleration of dung decomposition and nutrient cycling (Lee and Wall, 2006; Freymann et al., 2008; Nichols et al., 2008; O'Hea et al., 2010). Prolonged presence of dung pats on soil surface is a management concern for ranchers. Dung pats suppress growth of plants underneath the dung. Fouling by dung pats also deters animals from grazing the area surrounding the pat until the pat is incorporated into the soil (Pecenka and Lundgren, 2018). Introduction of dung beetles to accelerate dung degradation has been successful in reducing surface area covered by dung pats, which in turn promotes grazing on the area surrounding each dung pat previously avoided by grazing livestock (Nichols et al., 2008). The feeding habits of dung beetles also help in the suppression of dung-inhabiting pests to grazing cattle, another ecosystem service provided by dung beetles (Fincher, 1981; Nichols et al., 2008).

Dung nutrients are mainly in organic forms and must be mineralized and translocated into soil before assimilation by plants or soil microbes (Van Kessel et al., 2000; Calderón et al., 2004). The translocation of dung nutrients into the soil is largely related to decomposition rates that can vary from 1 to $4 \mathrm{mo}$, depending on environmental conditions (MacDiarmid and Watkin, 1972; Underhay and Dickinson, 1978; Holter, 1979; Dickinson et al., 1981; Anderson et al., 1984; Aarons et al., 2004; Lee and Wall, 2006). Decomposition can take up to $3 \mathrm{yr}$ if insecticides are used 
(Anderson et al., 1984; Strong, 1992). A slow dung degradation and nutrient cycling present a greater chance for nutrient losses by volatilization and/or rainfall runoff. Accelerated dung decomposition, therefore, is necessary for plant nutrient availability and improved future grazing and functionality of rangeland ecosystems (Whisenant, 1999; Bang et al., 2005).

Among the soil fauna, arthropods are the most significant contributors to the acceleration of dung decomposition and nutrient cycling (Lee and Wall, 2006; Freymann et al., 2008; O'Hea et al., 2010; Pecenka and Lundgren, 2018). Dung beetles in particular, due to their larger size and feeding and nesting habits, increase bioturbation and the cycling of nutrients into the soil (Bertone, 2004; Bang et al., 2005). Dung beetles feed on the liquid contents of dung and use remaining dung material for housing and food for their brood. On the basis of their nesting strategies, dung beetles are grouped in three functional groups: endocoprid (dweller), paracoprid (tunneler), and telecoprid (ball roller) (Halffter and Edmonds, 1982). The dwellers live and brood inside the dung pat; the tunnelers dig burrows in the soil below the dung pats and construct nesting chambers inside the burrows with dung materials. The ball-rollers form dung balls and roll them some distance away from the dung pat before burial into soil for their brood. Dung beetles affect environmental conditions and microbial diversity within the dung pats, thereby increasing mineralization of dung nutrients (Breymeyer and ZacharievaStoilova, 1975; Stevenson and Dindal, 1987; Yokoyama et al., 1991). Dung beetles also promote abundance of other arthropod communities, which further contribute to dung degradation (Pecenka and Lundgren, 2018).

Dung properties and factors affecting dung beetle abundance, diversity, and activity determine the contribution of dung beetles in dung decomposition and nutrient cycling rate. These factors include nutrient composition of the dung, dung moisture and temperature, dung size, weather, and other environmental conditions (Underhay and Dickinson, 1978; Holter, 1979; Dickinson et al., 1981; Finn and Giller, 2000). Presence of insecticide in dung can reduce dung colonization by invertebrates (Suarez et al., 2003). Seasonality of climate factors such as temperature can affect dung colonization (Errouissi et al., 2004); therefore, dung decomposition is faster in late spring compared with that in late summer (Lee and Wall, 2006). The effects of dung beetles on dung pats are proportional to their body size (Mittal, 1993; Piccini et al., 2015). 
Dung beetle activity may vary throughout the growing season depending on the species present (Holter, 1982; Doube, 1991; Whipple, 2011).

Our goal is to quantify the effect of dung beetles on the timing and magnitude of dung decomposition and subsequent changes in carbon $(\mathrm{C})$, nitrogen $(\mathrm{N})$, and phosphorus $(\mathrm{P})$ of dung pats and rangeland soils. Dung beetle abundance, properties of dung and soil, and environmental variables were measured to understand the decomposition of new dung deposits and nutrient translocation over the early and late summer seasons. To date, there have been 256 different species of dung beetles identified in Nebraska, with 11-15 of the species found in the Sandhills region of north central Nebraska (Ratcliffe and Paulsen, 2008; Whipple, 2011). There are 5.1 million ha of rangeland in the Sandhills of Nebraska, and, globally, rangeland accounts for $\approx 70 \%$ of the necessary forage used for beef and dairy production (Lund, 2007). Therefore, quantification of beetle effects on dung decomposition and nutrient cycling will provide greater understanding of the overall system process for adaptive rangeland management.

\section{Methods}

\section{Site Description}

Research was conducted on shallow-groundwater-fed meadows at the Barta Brothers Ranch (42¹3'28.65”N, 99³8'19.17"W, 773 m above sea level) during the growing seasons of 2014 and 2015. Soils are of the Els series, classified as a mixed, mesic Aquic Ustipsamments with sandy to fine sandy loam texture. Initial soil bulk density to 20 - cm depth was 1.44 $\mathrm{Mg} \cdot \mathrm{m}^{-3}$; soil organic matter content ranged between 14 and $33 \mathrm{mg} \mathrm{g}^{-1}$ at the 0 - to $10-\mathrm{cm}$ depth and $4-9 \mathrm{mg} \mathrm{g}^{-1}$ at the 10 - to 20 -cmdepth. The climate is semiarid with long-term average (1981-2010) annual precipitation of $584 \mathrm{~mm} \mathrm{y}^{-1}$ and annual air temperature of $9.6^{\circ} \mathrm{C}$. Eighty percent of the precipitation falls between April and September with May and June typically being the wettest months. Vegetation cover is dominated by exotic, cool-season grasses including redtop bent (Agrostis stolonifera L.), quackgrass (Elymus repens L.), timothy (Phleum pratense L.), Kentucky bluegrass (Poa pratensis L.), and smooth bromegrass (Bromus inermis Leyss.). Several species of sedges (Carex spp. L.) and rushes (Juncus spp. L.) are also common. Warm-season grasses are less common 
and include big bluestem (Andropogon gerardii Vitman), switchgrass (Panicum virgatum L.), and Indiangrass (Sorghastrum nutans L.). Exotic legumes, red clover (Trifolium pratense L.), and white clover (Trifolium repens L.), are prevalent throughout the study area. Common forbs include yarrow (Achillea millefolium L.), blackeyed Susan (Rudbeckia hirta L.), and Missouri goldenrod (Solidago missouriensis Nutt.). The study site was previously part of a hay meadow that had been cut for hay annually in July for the preceding several decades.

\section{Dung Collection and Making Dung Pat}

Dung was collected in winter yearly and stored in 16 plastic buckets (each has $19 \mathrm{~L}$ volume) at approximately-20 ${ }^{\circ} \mathrm{C}$ until use. Each bucket of dung was designated for each experimental block in each year-season combination. Before field application, dung was thawed, homogenized, and reconstituted by adding $\approx 4 \mathrm{~L}$ tap water to each bucket. Dung was frequently mixed inside the bucket during the application of treatments to ensure consistency across dung pats. Dung pats were made by adding $1.5 \mathrm{~L}$ of the reconstituted dung into a $20-\mathrm{cm}$ diameter plastic ring, resulting in an average thickness of $4.8 \mathrm{~cm}$. The making of dung pats followed the protocol of Pentillä et al. (2013).

The dung source was grain- and pasture-fed yearling steers that did not receive insecticidal treatment. Their diet consisted of $70.5 \%$ brome grass, $23.3 \%$ dry distillers grains plus solubles, $5.8 \%$ dry rolled corn, $0.28 \%$ salt, $0.05 \%$ beef trace mineral, and $0.03 \%$ vitamins $A, D$, and $E$. These steers were fed $6.9 \mathrm{~kg}$ of the diet while held off of pasture for observation. Dung analysis (per dry dung mass basis) was $20.8 \mathrm{~g} \mathrm{~kg}^{-1}$ total $\mathrm{N}, 20.7 \mathrm{~g} \mathrm{~kg}^{-1}$ organic $\mathrm{N}, 0.12 \mathrm{~g} \mathrm{~kg}^{-1} \mathrm{NH} 4,19.5 \mathrm{~g} \mathrm{~kg}^{-1} \mathrm{P}_{2} \mathrm{O}_{5}, 4.76 \mathrm{~g} \mathrm{~kg}^{-1}$ $\mathrm{K}_{2} \mathrm{O}, 3.06 \mathrm{~g} \mathrm{~kg}^{-1} \mathrm{~S}$, and $20.8 \mathrm{~g} \mathrm{~kg}^{-1} \mathrm{Ca}$, and dung C:N ratio was approximately 19:1.

\section{Experiment Design}

A split-plot design was conducted to determine the interacting effects of length of time (since placement of dung pats on surface of grassed land) on dung decomposition upon exposure to dung beetles. In June 2014, a site was divided into eight blocks (Fig. 1A); each block was $7.2 \times 3.6 \mathrm{~m}$ in size. Each block was further divided into six plots (whole-plots); each whole-plot was $3.6 \times 1.2 \mathrm{~m}$ in size (Fig. 1D). The six whole-plots within 


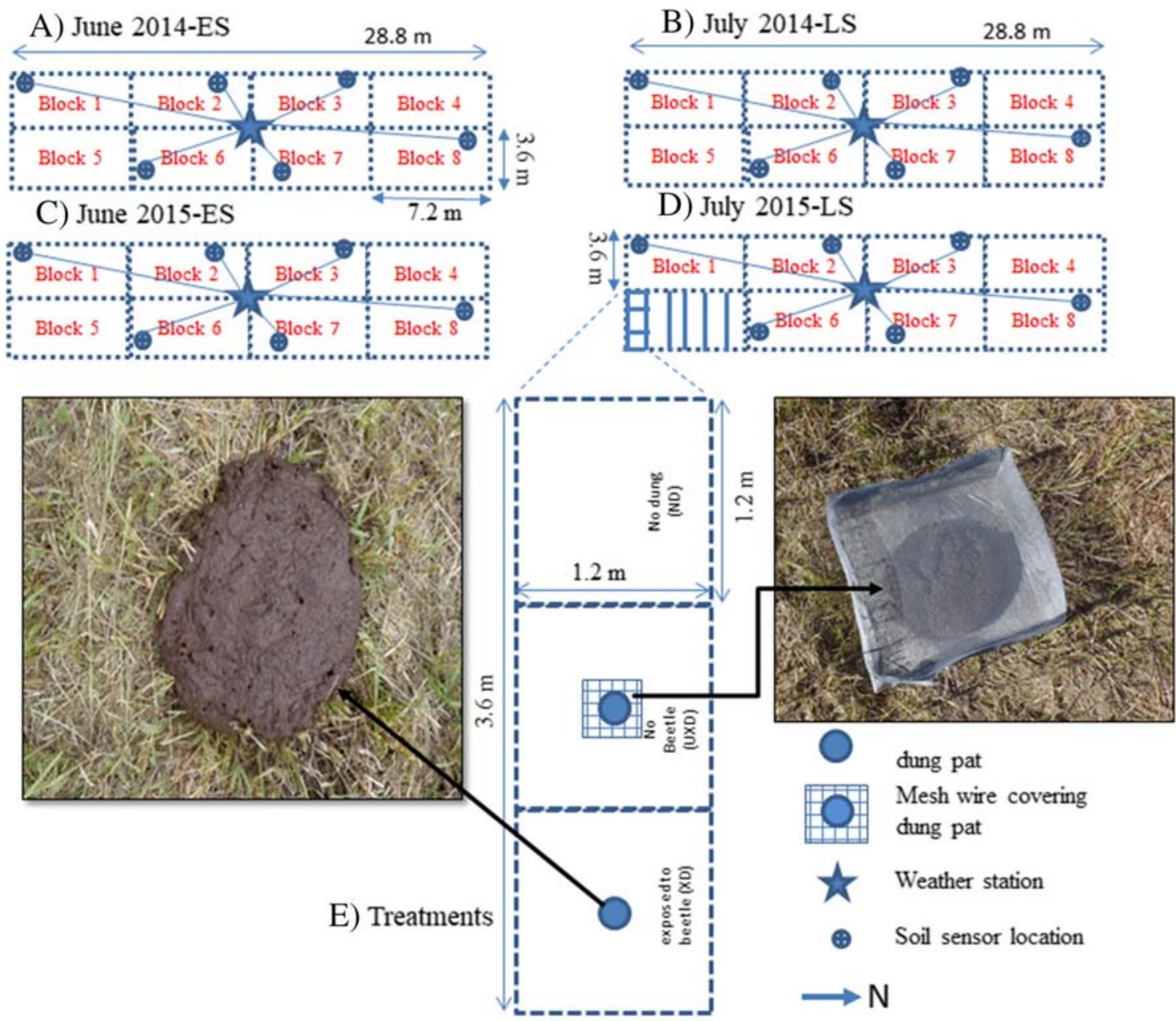

Figure 1. Experimental layout for placement of exposed dung (XD), unexposed dung (UXD), and no dung control (ND) on grassed soil early (June) in the summer season (ES) and late (July) in the summer season (LS) of 2014 and 2015 in meadows of the Nebraska Sandhills.

each block were randomly assigned to six sampling events (of dung and soil); that is, on $1,3,7,14,28$, and $56 \mathrm{~d}$ after placement (DAPs) of dung pats. Each whole-plot was further divided into three smaller subplots (split-plots); each split-plot was $1.2 \times 1.2 \mathrm{~m}$ in size as presented in Figure 1E. The three split-plots within each whole-plot were randomly assigned to three levels of dung treatments: 1) exposed dung (XD), dung pat was placed directly on the grassed soil surface; 2) unexposed dung (UXD), dung pat was placed in a wire-mesh-cage (1-mm holes) and then placed on the grassed soil surface; and 3) no dung (ND), control without dung on soil surface (Fig. 1E). The XD treatment enabled dung beetles 
or other soil fauna to colonize and/or exit the dung pat freely. The mesh cage of the UXD treatment $(\approx 38 \times 38 \times 18 \mathrm{~cm})$ covered the pat from the bottom, top, and sides to prevent dung beetle or other soil fauna colonization. The presence of the mesh also deterred other arthropods that were small enough to fit through the cage (Pecenka and Lundgren, 2018). On the basis of our preliminary experiment, it was assumed that mesh cage exhibited no significant effect on the physical conditions of dung pats including moisture or temperature. The six sampling events (within a 56-d collection period) resulted in 96 dung pats (48 pats unexposed to beetles and 48 pats exposed to beetles) and 48 units of control (no dung pat).

To evaluate how seasonal changes in environmental conditions affect decomposition of new dung deposits, the same experiment was conducted in July 2014 (Fig. 1B) and placed adjacent to the site constructed in June 2014. The treatment with dung application in June was identified as early in summer season (ES), and the treatment with dung application in July was identified as late in summer season (LS). Both experiments were repeated in 2015 (also in June and July) on adjacent locations (Fig. 1C and D). In 2014, the ES experimental period was from 10 June to 5 August and the LS experimental period was from 15 July to 12 September. In 2015, the ES experimental period was 8 June to $3 \mathrm{Au}$ gust, and the LS period was 14 July to 12 September.

\section{Sampling of Dung Pat and Soil}

At each sampling date, two dung pats (one exposed pat and one unexposed pat) were harvested from each of the 8 blocks (Fig. 1E) resulting a total of 16 dung pats per site. Six harvest-times, therefore, generated 96 pats per site, or a total of 384 dung pats from all four sites (see Fig. 1). After removal of a dung pat at each sampling date, four soil cores were immediately collected below each dung pat; another four soil cores were collected from four orthogonal points located $30 \mathrm{~cm}$ away from the edge of the dung pat. Four soil cores from four orthogonal points (30 $\mathrm{cm}$ apart) were also collected from the ND treatment. Soil cores were collected using a hand-held soil probe, $1.5-\mathrm{cm}$ in diameter. Soil cores were divided by depth at 0 - to $10-\mathrm{cm}$ and 10- to 20-cm depths and then combined by each depth. At each harvest time, the sampling protocol generated 32 soil samples from the XD treatment, 32 samples from the UXD treatment, and 16 samples from the ND treatment, totaling 80 soil 
samples. The six harvest times, therefore, generated 480 soil samples per site, or a total of 1920 soil samples from all four sites. Field-moist soil samples were sieved to pass 2-mm mesh. Dung and soil samples were placed into plastic freezer bags and stored at $-20^{\circ} \mathrm{C}$ until analyses. Before analysis, dung samples were thawed, weighed, and homogenized. One quarter of each homogenized dung pat was used for beetle survey, another quarter was used for moisture and dry matter (DM) determination, and the other half was used for chemical analyses.

Beetle presence was determined by both floating and sieving survey methods. The floatation survey method is performed by placing $\approx 100 \mathrm{~g}$ of field-moist dung material into $1000 \mathrm{~mL}$ of water, stirring until dung is completely broken up,waiting $\approx 45 \mathrm{~min}$ for dung material to become saturated with water, stirring once more to free beetles from dung material, and then collecting beetles that float to the surface of the water (Whipple, 2011). Beetles were then counted and identified. The number of beetles counted in the one-quarter pat was not scale-up to the whole pat. Our emphasis was to find the dynamics of dung beetle abundance over the sampling times. In this experiment, no measurements of the roller beetles, tunneler beetles, and other soil fauna were made.

Dung pat moisture and DM contents were determined after oven drying at $60{ }^{\circ} \mathrm{C}$ for $72 \mathrm{~h}$. We present dung moisture in dry-weight basis (water/DM) because dung moisture in wet-weight basis (water/ (water $+\mathrm{DM}$ )) is not sensitive to water loss when dung is wet (within the first 7 DAPs).

Dung and soil were analyzed for water extractable organic carbon (WEOC), water extractable N (WEN), and water extractable P (WEP). The WEOC, WEN, and WEP were obtained after 1-h extraction of fieldmoist dung and soil in deionized water at a dung/water ratio of 200:1 and a soil/water ratio of 5:1. Dung and soil were also extracted in $2 M$ KCL for analysis of dung $\mathrm{NH}_{4}$, soil $\mathrm{NH}_{4}$, and $\mathrm{NO}_{3}$.

The organic $\mathrm{C}$ and $\mathrm{N}$ of extracts were determined on Shimadzu 5200 Liquid analyzer (Shimadzu Corp., Kyoto, Japan). Phosphorus was determined colorimetrically by the molybdate method (Murphy and Riley, 1962) at $880 \mathrm{~nm}$ using a Thermo Scientific Genesys 10S VIS Spectrophotometer (ThermoFisher Scientific Inc., Waltham, MA). The $\mathrm{NH}_{4}$ and $\mathrm{NO}_{3}$ were determined by the flow injection method (Ružicka and Hansen, 1988) using a Lachat Quikchem 8000 (Lachat Instruments, Inc., Loveland, CO). 
Table 1. Means and standard error $(n=24)$ of content or mass of dung moisture, dry matter (DM) and dung chemical analytes (on dung dry weight basis) at $0 \mathrm{~d}$ after placement (DAP) of dung.

\begin{tabular}{|c|c|c|c|c|c|}
\hline \multirow[b]{2}{*}{ Analyte $^{1}$} & \multicolumn{4}{|c|}{ Yr-Season } & \multirow[b]{2}{*}{ Average } \\
\hline & 2014-ES & 2014-LS & 2015-ES & 2015-LS & \\
\hline DM $\left(\right.$ g pat $\left.^{-1}\right)$ & $303 \pm 7$ & $289 \pm 6$ & $275 \pm 6$ & $235 \pm 3$ & $275 \pm 4$ \\
\hline Moisture $\left(\mathrm{g} \mathrm{g}^{-1}\right)$ & $4.2 \pm 0.1$ & $4.4 \pm 0.1$ & $4.5 \pm 0.1$ & $5.3 \pm 0.1$ & $4.6 \pm 0.1$ \\
\hline WEOC (ug C g-1) & $11875 \pm 769$ & $8029 \pm 666$ & $3901 \pm 83$ & $4407 \pm 95$ & $7002 \pm 412$ \\
\hline WEOC (mg C pat $\left.{ }^{-1}\right)$ & $3657 \pm 305$ & $2385 \pm 232$ & $1071 \pm 9$ & $1039 \pm 30$ & $2010 \pm 128$ \\
\hline WEN (ug N g ${ }^{-1}$ ) & $2165 \pm 98$ & $1423 \pm 85$ & $710 \pm 29$ & $733 \pm 15$ & $1248 \pm 69$ \\
\hline WEN (mg N pat ${ }^{-1}$ ) & $663 \pm 42$ & $419 \pm 31$ & $195 \pm 9$ & $172 \pm 5$ & $358 \pm 22$ \\
\hline WEP (ug P g ${ }^{-1}$ ) & $2277 \pm 78$ & $1882 \pm 89$ & $5142 \pm 192$ & $5066 \pm 343$ & $3606 \pm 167$ \\
\hline WEP (mg P pat ${ }^{-1}$ ) & $689 \pm 27$ & $542 \pm 27$ & $1398 \pm 42$ & $1188 \pm 81$ & $958 \pm 38$ \\
\hline $\mathrm{NH}_{4}\left(\mathrm{ug} \mathrm{N} \mathrm{g}^{-1}\right)$ & $422 \pm 22$ & $324 \pm 12$ & $1733 \pm 85$ & $1317 \pm 117$ & $954 \pm 65$ \\
\hline $\mathrm{NH}_{4}\left(\mathrm{mg} \mathrm{N} \mathrm{pat}{ }^{-1}\right)$ & $128 \pm 8$ & $94 \pm 4$ & $471 \pm 21$ & $307 \pm 26$ & $252 \pm 16$ \\
\hline
\end{tabular}

1. Analytes were water-extractable organic carbon (WEOC), water-extractable N (WEN),waterextractable P (WEP), and ammonium $\left(\mathrm{NH}_{4}\right)$; analyte mass per pat was calculated as the multiplication of DM mass per pat and analyte content.

\section{Properties of Dung Pats Before Placement}

Differences in moisture, DM weight, and analyte content of dung pats resulted in application rate differences in dung DM, WEOC, WEN, WEP, and $\mathrm{NH}_{4}$ - $\mathrm{N}$ among the year-season combinations (Table 1). Inherent differences in dung application rate and initial content of dung analytes (see Table 1) warrant standardization of dung moisture, DM, and analyte data. Data standardization, by division with their respective initial (at 0 DAP) values, would minimize inherent bias caused by the differing initial values of dung content and application rate.

\section{Ancillary Environmental Data}

Environmental data were intended to describe weather and soil conditions across each experimental site (see Fig. 1). Environmental data were not associated with a particular dung treatment. Hourly soil and weather data were recorded on the experimental site with a data logger (Campbell Scientific CR1000, Logan, UT). Instruments and sensors for weather data collection were installed at the center of the experimental 
site before dung application (see Fig. 1A-D). Air temperature and relative humidity were measured with a Campbell Scientific WXT520 weather sensor, and precipitation was measured with a tipping bucket pluviometer (Campbell Scientific Inc., Logan, UT).

Soil sensors were installed on dung-free areas at six (out of 8) blocks at a distance of 3,7 , and $11 \mathrm{~m}$ from the center of the experimental site (Fig. 1A-D). Soil sensors were buried at $10-\mathrm{cm}$ and $20-\mathrm{cm}$ depths. Soil temperature and water content were measured with Campbell Scientific CR655 soil water content reflectometer sensors.

\section{Statistical Design and Analysis}

Data on dung pat decomposition indicators, physical and chemical properties, were analyzed to fit a multiyear-season experiment, where the combined analysis of variance over years and seasons are based on splitplot experimental design. The whole-plot factor was harvest time (DAPs) of dung pats, and the split-plot factor was dung treatment. Year, season, DAP, dung treatment, and their interactions were considered fixed effects. The random effects, error terms, are nested within the variables year and season (i.e., block [year-season], block X DAP [year-season], and residuals [block X treatments \{year-season DAP $\}$ ]).

Data of soil underneath the dung and data of soils $30 \mathrm{~cm}$ away from the dung were analyzed separately to fit a balanced-data experiment, where the combined analysis of variance over years and seasons are based on split-split-plot experimental design. Note, soil samples of the ND treatment were applied for both sampling positions, underneath dung pat and $30 \mathrm{~cm}$ away from dung pat. The whole-plot factor was DAP, the split-plot factor was treatment, and the split-split-plot factor was soil depth.

Statistical analysis of variance used PROC MIXED procedure of SAS version 9.4 (Little et al., 1996; SAS, 2014, SAS Institute, Cary, NC). The least square means \pm standard error (LSMeans $\pm \mathrm{SE}$ ) and their difference were used for means separations when the test of fixed effects indicated significance at $\alpha=0.05$. Principal component analysis (PCA) was done to summarize environmental (weather and soil) variables. The PCA was done on the correlation matrix of the environmental variables using the PRINCOMP procedure of SAS. 


\section{Results}

\section{Dung Beetle Abundance}

Placing dung pats in the 1-mmmesh box for UXD treatment (Fig. 1) was effective against colonization of the dung pats by dung beetles. Only 10 out of the 192 (5.2\%) UXD dung pats contained beetles (Table 2). Only one UXD dung pat (out of eight) had one dung beetle at 3 DAPs in the 2014-ES; in the 2014-LS period, no UXD dung pat contained beetle. In 2015 , the frequency and count of dung beetle of the UXD treatment were slightly higher than that of 2014 (see Table 2).

In the XD treatment, frequency and count of dung beetle varied with year-season combinations. The 56-d total of dung beetle frequency and count during the 2014-ESwas doubled that of the 2014-LS (see Table 2). The difference between the 2015-ES and 2015-LS in the 56-d total dung frequency and count was not conclusive because of missing data; no beetle survey was made for two sampling events. Consistent within

Table 2. Dung beetle counts and number of dung pats (out of 8) occupied by the beetles (frequency) in exposed dung (XD) and unexposed dung (UXD) treatments at various d after placement (DAP) of dung pats during early in season (ES) and later in season (LS) periods in 2014 and 2015.

\begin{tabular}{|c|c|c|c|c|c|c|c|c|c|}
\hline \multirow[b]{3}{*}{ Year } & \multirow[b]{3}{*}{ DAP } & \multicolumn{4}{|l|}{ ES } & \multicolumn{4}{|l|}{ LS } \\
\hline & & \multicolumn{2}{|l|}{ XD } & \multicolumn{2}{|l|}{ UXD } & \multicolumn{2}{|l|}{$\mathrm{XD}$} & \multicolumn{2}{|l|}{ UXD } \\
\hline & & Freq. & Count & Freq. & Count & Freq. & Count & Freq. & Count \\
\hline \multirow[t]{7}{*}{2014} & 1 & 5 & 14 & 0 & 0 & 1 & 1 & 0 & 0 \\
\hline & 3 & 8 & 17 & 1 & 1 & 7 & 10 & 0 & 0 \\
\hline & 7 & 5 & 5 & 0 & 0 & 4 & 10 & 0 & 0 \\
\hline & 14 & 3 & 4 & 0 & 0 & 0 & 0 & 0 & 0 \\
\hline & 28 & 1 & 2 & 0 & 0 & 0 & 0 & 0 & 0 \\
\hline & 56 & 0 & 0 & 0 & 0 & 0 & 0 & 0 & 0 \\
\hline & Total & 22 & 42 & 1 & 1 & 12 & 21 & 0 & 0 \\
\hline \multirow[t]{7}{*}{2015} & 1 & 1 & 6 & $\mathrm{~N} / \mathrm{A}$ & $\mathrm{N} / \mathrm{A}$ & $\mathrm{N} / \mathrm{A}$ & $\mathrm{N} / \mathrm{A}$ & $\mathrm{N} / \mathrm{A}$ & $\mathrm{N} / \mathrm{A}$ \\
\hline & 3 & 4 & 24 & 1 & 1 & 5 & 19 & 2 & 2 \\
\hline & 7 & 2 & 9 & 1 & 1 & 3 & 23 & 0 & 0 \\
\hline & 14 & $\mathrm{~N} / \mathrm{A}$ & $\mathrm{N} / \mathrm{A}$ & 2 & 2 & 3 & 6 & 2 & 2 \\
\hline & 28 & $\mathrm{~N} / \mathrm{A}$ & $\mathrm{N} / \mathrm{A}$ & $\mathrm{N} / \mathrm{A}$ & $\mathrm{N} / \mathrm{A}$ & $\mathrm{N} / \mathrm{A}$ & $\mathrm{N} / \mathrm{A}$ & $\mathrm{N} / \mathrm{A}$ & $\mathrm{N} / \mathrm{A}$ \\
\hline & 56 & 0 & 0 & 0 & 0 & 0 & 0 & 1 & 2 \\
\hline & Total & 7 & 39 & 4 & 4 & 11 & 48 & 5 & 6 \\
\hline
\end{tabular}

$\mathrm{N} / \mathrm{A}$ indicates that no dung beetle survey was made. 
each year-season combination of the XD treatment were 1) frequency of beetle-occupied dung pats were highest at 3 DAPs; 2) dung beetle count was highest at 3 and 7 DAPs; and 3) dung beetle count was less at 14 and 28 DAP and no beetle was found in dung pats at 56 DAPs (see Table 2).

Differences in initial dung physical and chemical properties among seasons (see Table 1) had no significant effect on dung beetle counts. Lack of contrast in initial size and weight of dung pats (because the pat was made using the same molding) resulted in no correlation between dung initial physical properties and dung beetle counts. When the range of pat sizes are large, Finn and Giller (2000) observed a positive relationship between dung pat size and dung beetle density across all sampling dates in a field experiment. In our study, the Pearson correlation between dung count and initial dung moisture content $(r=0.68, P>$ $|r|=0.04$ ) was observed only at 7 DAPs of the 2014-ES season. The Pearson correlations between dung beetle counts with all initial dung chemical properties were not significant at $\alpha=0.05$.

Dung beetle counts in our experiments (see Table 2) were much higher than those reported by Wagner (2016) in a 2-month experiment using a beetle pitfall trap in hayed rangeland at the same Bartha Brothers Ranch. Wagner (2016) observed that fewer than 5 beetles were trapped in 2014 or 2015 . Dung beetle counts in our experiments were within the range of beetle counts observed by Pecenka and Lundgren (2018); their observation indicated that dung beetle represented $1.5-3 \%$ of the total arthropods abundance in a 42-d experiment on a grazed pasture in South Dakota.

\section{Changes in Dung Physical Properties}

Significant treatment $\times$ DAP interaction on dung moisture (Table 3) indicated differences in moisture loss rate among sampling intervals (Fig. 2A). Dung moisture content (see Fig. 2A) in the XD and UXD treatments at 7 DAPs was $45 \%$ and $52 \%$ of initial moisture content of $4.6 \pm 0.1 \mathrm{~g}$ $\mathrm{g}^{-1}$ (see Table 1), respectively. At 56 DAPs, remaining dung moisture of the XD was $14 \% \pm 1 \%$ of the initial moisture content, lower than that of the UXD $(17 \% \pm 1 \%)$. Lower dung moisture content of the XD treatment indicated higher moisture loss rates than those of the UXD treatment within the first 7 DAP (see Fig. 2A), which co-occurred with higher frequency and count of beetles in the XD dung pats. 
Table 3. Statistical $F$ and $P>F$ values of fixed effects of yr (Y), season (S), treatment (T), d after placement (DAP), and their interactions on dung moisture, dry matter (DM), water extractable organic carbon (WEOC), water extractable $\mathrm{N}$ (WEN), water extractable P (WEP), and ammonium $\left(\mathrm{NH}_{4}\right)$ of rangeland soils of Nebraska Sandhills.

\begin{tabular}{lllllllll} 
Effects & NDF & DDF & Moisture & DM & WEOC & WEN & WEP & $\mathrm{NH}_{4}$ \\
\hline $\mathrm{Y}$ & 1 & 28 & $7.88^{* *}$ & $5.42^{*}$ & $26.99^{* * *}$ & $13.12^{* *}$ & $12.04^{* *}$ & 3.4 \\
$\mathrm{~S}$ & 1 & 28 & 0.24 & $18.66^{* * *}$ & 3.43 & $14.23^{* * *}$ & $83.48^{* * *}$ & $9.34^{* *}$ \\
$\mathrm{Y} \times \mathrm{S}$ & 1 & 28 & $51.65^{* * *}$ & $12.62^{* *}$ & $21.77^{* * *}$ & $8.58^{* *}$ & $7.74^{* *}$ & $12.6^{* *}$ \\
$\mathrm{DAP}$ & 5 & 140 & $1125.48^{* * *}$ & $59.05^{* * *}$ & $40.39^{* * *}$ & $239.76^{* * *}$ & $11.82^{* * *}$ & $38.05^{* * *}$ \\
$\mathrm{Y} \times \mathrm{DAP}$ & 5 & 140 & $28.35^{* * *}$ & $4.03^{* *}$ & $12.93^{* * *}$ & $49.01^{* * *}$ & $3.54^{* *}$ & $25.49^{* * *}$ \\
$\mathrm{~S} \times \mathrm{DAP}$ & 5 & 140 & $35.46^{* * *}$ & $5.29^{* * *}$ & $7.81^{* * *}$ & $7.46^{* * *}$ & $7.36^{* * *}$ & $10.03^{* * *}$ \\
$\mathrm{Y} \times \mathrm{S} \times \mathrm{DAP}$ & 5 & 140 & $13.13^{* * *}$ & 0.59 & $24.47^{* * *}$ & $27.38^{* * *}$ & $4.72^{* * *}$ & $15.56^{* * *}$ \\
$\mathrm{~T}$ & 1 & 168 & $141.17^{* * *}$ & $12.58^{* * *}$ & 0.14 & 3.31 & 0.04 & 0.02 \\
$\mathrm{Y} \times \mathrm{T}$ & 1 & 168 & 0 & 0.6 & 0.44 & 0.4 & $3.99^{*}$ & $10.78^{* *}$ \\
$\mathrm{~S} \times \mathrm{T}$ & 1 & 168 & 0.09 & 2.22 & 0.46 & 0.07 & 0.15 & $5.1^{*}$ \\
$\mathrm{Y} \times \mathrm{S} \times \mathrm{T}$ & 1 & 168 & 1.93 & 0 & 0 & 0.44 & 2.17 & 1.09 \\
$\mathrm{DAP} \times \mathrm{T}$ & 5 & 168 & $7.03^{* * *}$ & 0.93 & 2.08 & 1.91 & 0.74 & 0.53 \\
$\mathrm{Y} \times \mathrm{DAP} \times \mathrm{T}$ & 5 & 168 & 0.83 & 1.82 & 1.03 & 1.38 & 1.34 & 1.57 \\
$\mathrm{~S} \times \mathrm{DAP} \times \mathrm{T}$ & 5 & 168 & $3.16^{* *}$ & 0.55 & 0.29 & 1.61 & 0.83 & 1.05 \\
$\mathrm{Y} \times \mathrm{S} \times \mathrm{DAP} \times \mathrm{T}$ & 5 & 168 & 0.74 & 0.43 & 1.77 & $2.65^{*}$ & 1.07 & 1.36 \\
\hline$* * * 4$ & & & & & & & &
\end{tabular}

$*, * *, * * *$ indicated that $F$ values are significant at alpha $0.05,0.01$, and 0.001 , respectively.

$\dagger$ Three treatment levels are unexposed dung (UXD), exposed dung (XD), and no dung (ND).

$\ddagger$ Two levels of season were early in season (ES) from June to August and later in season (LS) from July to September.

$\S$ Dung measurements were made $0,1,3,7,14,28$, and $56 \mathrm{~d}$ after placement (DAP) of dung pats during the ES and LS periods.

The moisture loss rate during sampling intervals of $0-1,1-3$, and 3-7 DAPs (see Fig. 2A) in the XD treatment was 10.5\%, 8.8\%, and 7.1\%/ d, respectively; the corresponding dung moisture loss rate in the UXD treatment was $7.7 \%, 7.5 \%$, and $6.4 \% / \mathrm{d}$, respectively. For the sampling intervals 7-14 DAPs and thereafter, the moisture loss rates in the XD and UXD were $<1.3 \% / \mathrm{d}$. The relation between dung moisture and DAP fitted well a three-parameter exponential decay function (see Fig. 2A). The moisture loss rate (the slope of regression line) in the UXD and XD treatment can be expressed as $-8.03 e^{-0.1078 D A P}$ and $-12.3 e^{-0.1573 D A P}$, respectively. The moisture loss rate indicated that differences in the moisture loss rate (between the XD and UXD) decreased with increasing DAP. At 30 DAPs or later, after losing $>73 \%$ moisture (desiccated state), estimated dung moisture loss in both XD and UXD treatments was $<0.1 \% / \mathrm{d}$. 


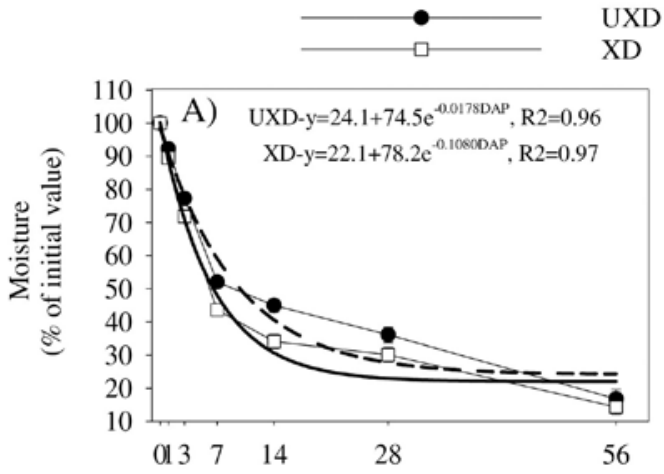

UXD
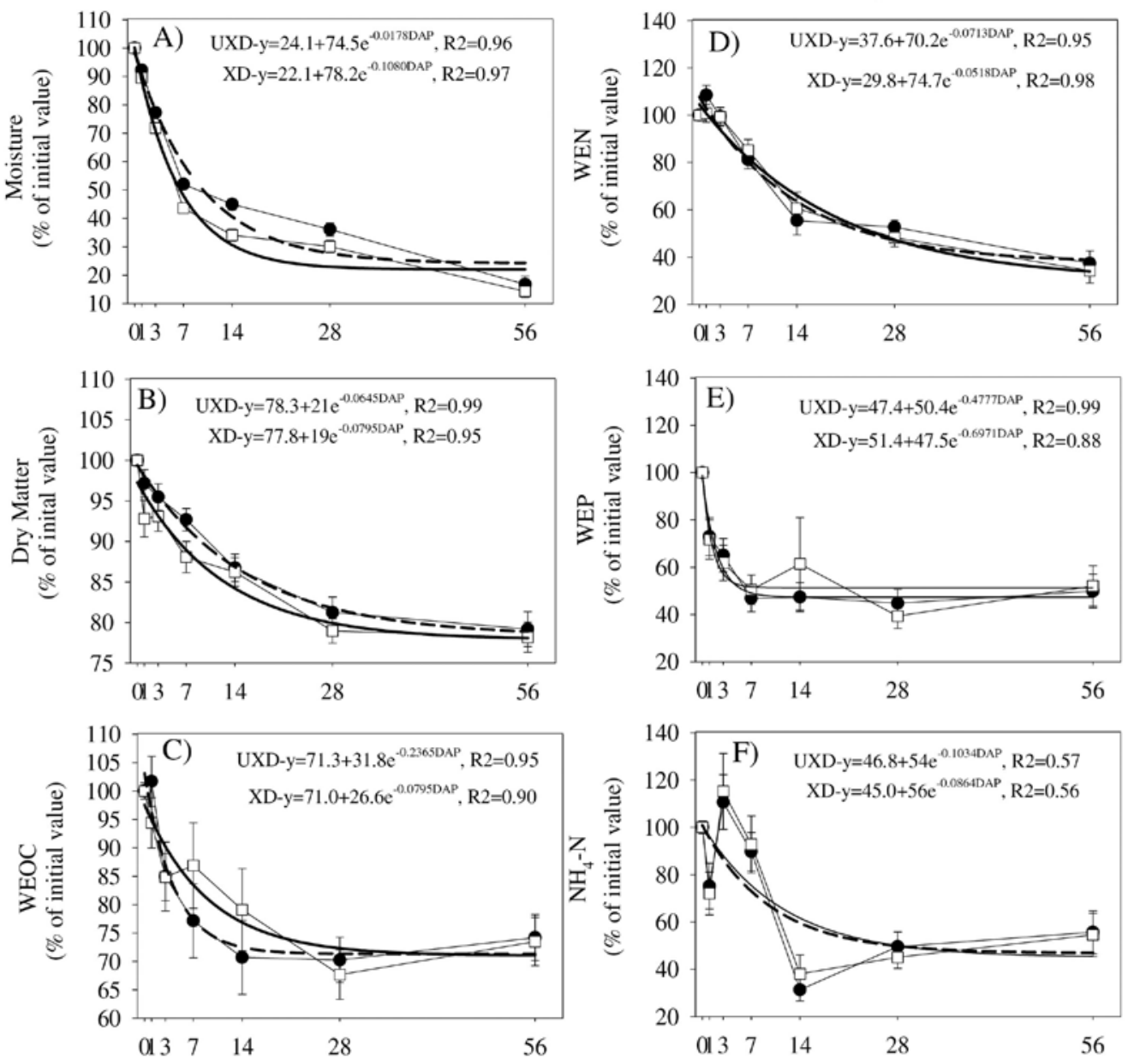

Day After Placement (DAP)

Figure 2. Dung analyte contents as percentage of initial values on day after placement (DAP) of exposed dung (XD) and unexposed dung (UXD); A) moisture, B) dry matter, C) water extractable organic carbon, WEOC, D) Water extractable nitrogen, WEN, E) water extractable phosphorus, WEP, F) NH4-N.

Significant treatment effect on dung DM (see Table 3) indicated that the LSMeans ( $n=192$, averaged over 2 yr, 2 seasons, 6 DAP, 8 replications) of dung DM in the UXD treatment ( $89 \% \pm 1 \%$ of initial value) was higher than that of the XD treatment ( $86 \% \pm 1 \%$ of initial value), especially at 1 and 7 DAPs (Fig. 2B). At 7 DAPs, the LSMeans of the DM mass in the UXD and XD treatment was $92 \% \pm 1.5 \%$ and $88 \% \pm 1.5 \%$ of the initial DM mass of $275 \pm 4 \mathrm{~g} \mathrm{pat}^{-1}$ (see Table 1), respectively. The dung DM loss rate during sampling intervals of $0-1$, and 3-7 DAPs (Fig. 2B) in 
the XD treatment was $7.2 \%$ and $1.2 \% / \mathrm{d}$, respectively; the corresponding dung DM loss rate in the UXD treatment was $2.9 \%$ and $0.7 \% / \mathrm{d}$. For the sampling intervals at 7-14 DAPs or later, the DM loss rates in the XD and UXD were $<0.8 \% / d$ (see Fig. 2B).

The relation between dung DM and DAP fitted well a three-parameter exponential decay function (see Fig. 2B). The dung DM loss rate (the slope of regression line) in the UXD and XD treatment can be expressed as $-1.35 e^{-0.0645 D A P}$ and $1.54 e^{-0.0795 D A P}$, respectively. The dung DM loss rate indicated that differences in the DM loss rate (between the XD and UXD) decreased with increasing DAP. The slopes were similar between the UXD and XD treatment after 7 DAPs (see Fig. 2B). At 30 DAPs or later (desiccated state), dung DM loss rate was $<0.2 \% / \mathrm{d}$ in both the XD and UXD treatments.

\section{Changes in Dung Chemical Content and Mass}

The effects of treatment or treatment $\times$ DAP interaction on dung chemical analytes were not significant (see Table 3). The results (see Fig. 2C-F) suggested that beetles had no observable effects on changes in content of dung chemical analytes. Average of dung WEOC content at 56 DAPs (see Fig. 2C) was 74\% $3 \%$ of initial value (see Table 1), a $26 \%$ decrease. The rate of decrease in contents of dung WEN (see Fig. 2D), WEP (see Fig. 2E), and $\mathrm{NH}_{4}-\mathrm{N}$ (see Fig. $2 \mathrm{~F}$ ) were higher in the first 14 DAP and decreased thereafter. The decreasing rate of dung analytes over time fit with a three-parameter exponential decay function (Fig. 2). At 14 DAPs, the LSmeans of dung WEN, WEP, and NH4-N contents was $58 \% \pm 2 \%$, $54 \% \pm 5 \%$, and $35 \% \pm 6 \%$, respectively, of their initial values (see Table 1 ), reflecting an average decrease of $3 \%, 3.3 \%$, and $4.6 \% / \mathrm{d}$ of WEN, WEP, and $\mathrm{NH}_{4}$ contents, respectively.

The lack of differences in contents of WEOC, WEN, WEP, and $\mathrm{NH}_{4}-\mathrm{N}$ resulted in similar mass loss of the analytes in the XD than the UXD treatments at most DAP (Table 4). Differences in WEOC and WEN mass loss were observed only at $1 \mathrm{DAP}$, and no differences were observed between XD and UXD in mass loss of dung analytes at all other DAP (see Table 4).

\section{Seasonal Characteristics of Environmental Data and Dung Properties}

Significant year $\times$ season $\times$ DAP interactions (see Table 3 ) indicated complex effects of environmental conditions on dung decomposition. 
Table 4. Means of mass loss of dung water extractable organic carbon (WEOC), Water extractable nitrogen (WEN), water extractable phosphorus (WEP), and $\mathrm{NH}_{4}-\mathrm{N}$ of exposed (XD) and unexposed (UXD) treatments of dungs to soil fauna at various d after placement (DAP) of dung on grassed soil.

\begin{tabular}{|c|c|c|c|c|c|c|c|}
\hline \multirow[b]{2}{*}{ Analyte Loss* } & \multirow[b]{2}{*}{ Treatment } & \multicolumn{6}{|c|}{ DAP } \\
\hline & & 1 & 3 & 7 & 14 & 28 & 56 \\
\hline \multirow[t]{2}{*}{ WEOC $\left(\mathrm{mg} \mathrm{C} \mathrm{pat}{ }^{-1}\right)$} & UXD & $75 \pm 89 \dagger$ & $385 \pm 99$ & $464 \pm 93$ & $785 \pm 154$ & $814 \pm 103$ & $814 \pm 130$ \\
\hline & $\mathrm{XD}$ & $293 \pm 123$ & $487 \pm 111$ & $451 \pm 105$ & $667 \pm 149$ & $861 \pm 105$ & $842 \pm 149$ \\
\hline \multirow[t]{2}{*}{ WEN (mg N pat ${ }^{-1}$ ) } & UXD & $15 \pm 18 \dagger$ & $34 \pm 15$ & $71 \pm 14$ & $175 \pm 24$ & $185 \pm 17$ & $213 \pm 17$ \\
\hline & $\mathrm{XD}$ & $49 \pm 21$ & $57 \pm 19$ & $83 \pm 14$ & $153 \pm 22$ & $192 \pm 16$ & $225 \pm 21$ \\
\hline \multirow[t]{2}{*}{ WEP (mg P pat $\left.{ }^{-1}\right)$} & UXD & $240 \pm 95$ & $341 \pm 88$ & $523 \pm 68$ & $575 \pm 68$ & $630 \pm 60$ & $615 \pm 73$ \\
\hline & $\mathrm{XD}$ & $302 \pm 92$ & $382 \pm 85$ & $525 \pm 70$ & $490 \pm 164$ & $672 \pm 62$ & $636 \pm 82$ \\
\hline \multirow[t]{2}{*}{$\mathrm{NH}_{4}\left(\mathrm{mg} \mathrm{N} \mathrm{pat}^{-1}\right)$} & UXD & $10 \pm 15$ & $-8 \pm 18$ & $55 \pm 20$ & $142 \pm 17$ & $120 \pm 18$ & $130 \pm 25$ \\
\hline & $\mathrm{XD}$ & $17 \pm 13$ & $-9 \pm 23$ & $74 \pm 22$ & $142 \pm 21$ & $127 \pm 18$ & $134 \pm 25$ \\
\hline
\end{tabular}

* Loss is the difference between analyte initial mass (0 DAP) and the mass at corresponding DAPs.

${ }^{\dagger} \mathrm{XD}$ and UXD treatment were different at corresponding DAPs.

The PCA indicated that the first principal components (PC1) explained the majority (63\%) of total variability of environmental data. The PCA analysis selected soil temperature and soil VWC at $10-\mathrm{cm}$ depth as a summary for the rest of the environmental factors. The PC1 indicated positive loading of soil temperature and negative loading of soil VWC (Fig. 3A). The inverse loading of soil temperature and moisture indicated that as the soil temperature increased, the soil VWC decreased. Labeling the observations with ES and LS seasons showed that most of the observations during LS season had temperature higher than 22 ${ }^{\circ} \mathrm{C}$ and soil VWC $<0.16 \mathrm{~m}^{3} \mathrm{~m}^{-3}$ in the top $10-\mathrm{cm}$ depth (see Fig. 3A). On the contrary, soil temperature was lower and soil VWC at 10-cm depth was higher during the ES season. Most observations during the ES season had a soil temperature $<22^{\circ} \mathrm{C}$ and soil VWC higher than $0.16 \mathrm{~m}^{3}$ $\mathrm{m}^{-3}$ (see Fig. 3A).

The soil environmental effect on dung moisture was expected because the dung pats interfaced with the soil surface. Dung moisture during the 2015-ES was consistently higher than that of the 2015-LS season (see Fig. 3B). The LSmeans ( $n=96$, averaged over 2 treatments, 6 sampling events, and 8 replications) of dung moisture in the 2015-ES and 2015LS seasons were $58 \% \pm 1 \%$ and $47 \% \pm 1 \%$ of initial moisture, respectively. In 2014, dung moisture differences between the ES and LS seasons were not consistent in all DAP (see Fig. 3B). 

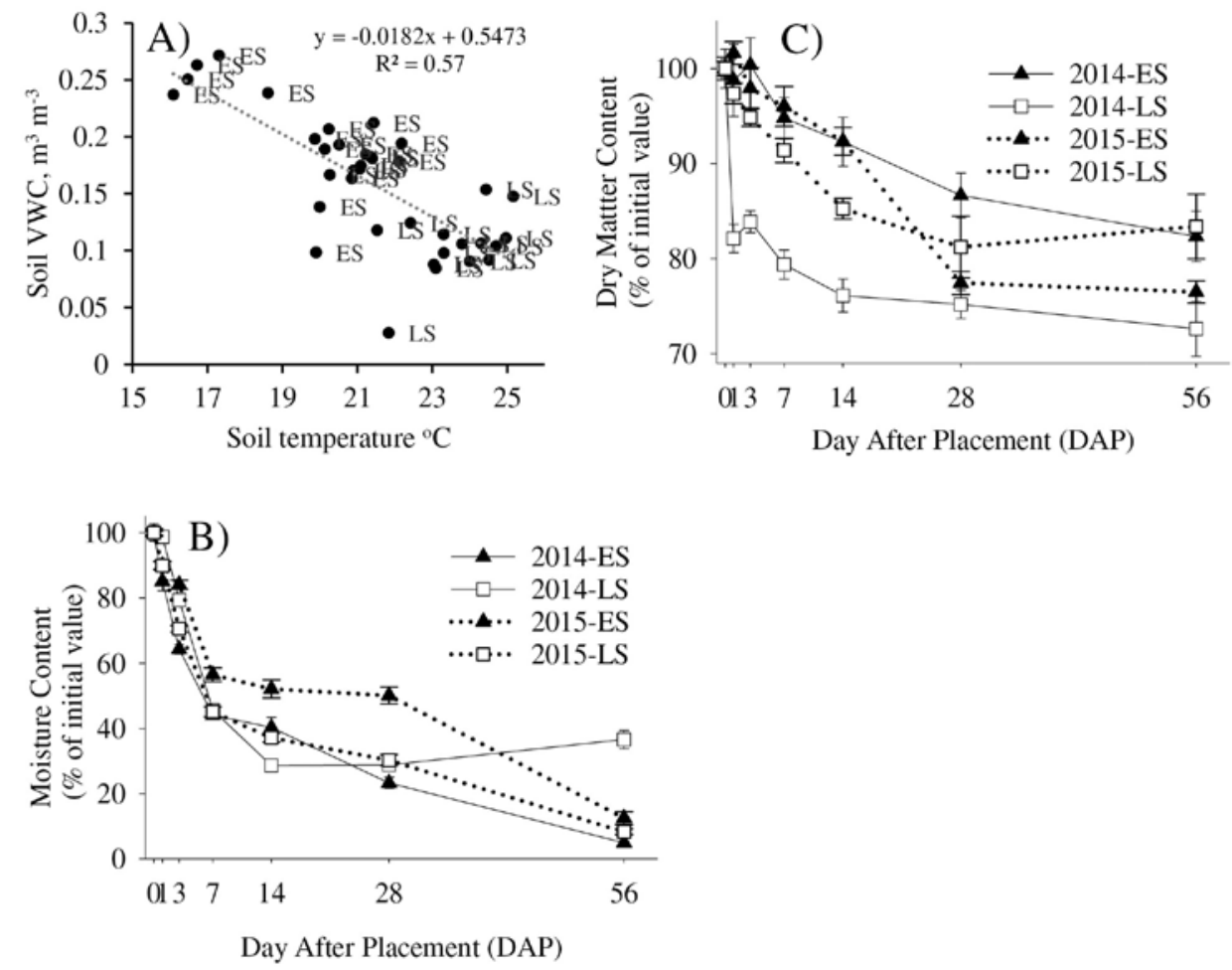

Figure 3. Seasonal characteristics of A) soil temperature and volumetric water content at 0 to $10 \mathrm{~cm}$ depth, B) dung moisture and C) dung dry matter.

The dung DM during the 2014-LS was consistently lower than that during the 2014-ES, which was mainly due to a $16 \%$ DM loss at interval 0-1 DAP (see Fig. 3C). The LSmeans ( $n=96)$ of dung DM in the 2014ES and 2014-LS seasons were $93 \% \pm 2 \%$ and $78 \% \pm 2 \%$, respectively. In 2015, the differences in dung DM between ES and LS were not consistent (see Fig. 3C).

The PCA analysis indicated that dung WEOC, WEN, WEP, and $\mathrm{NH}_{4}$ contents were distributed on wide ranges of PC1; therefore, how soil temperature and volumetric water content affected content of these dung chemical analytes were not clear.

Changes in Analytes of Soil Beneath Dung Pat

Soil analytes were stratified with depth; analytes' content at the 0 - to 10 $\mathrm{cm}$ depth were greater than those in the 10- to 20 -cm depth, even in the control ND treatment (Fig. 4). Amplitude of fluctuations of soil analytes in the 10- to $20-\mathrm{cm}$ depth was minimal compared with the amplitude of 


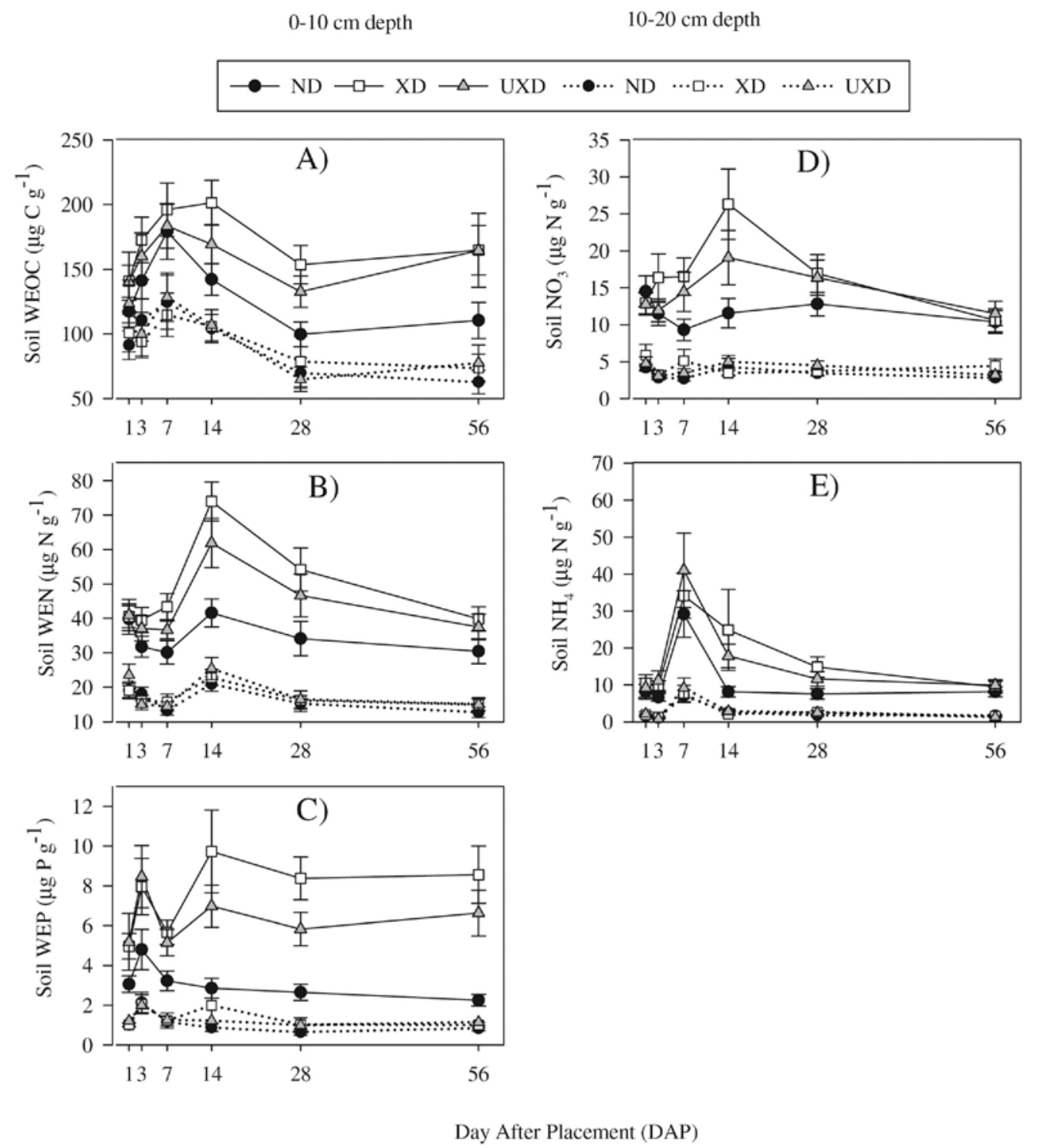

Figure 4. Soil analyte content at 0 to $10-\mathrm{cm}$ and 10 to $20-\mathrm{cm}$ depth, measured at days after placement (DAP) of exposed dung (XD), unexposed dung (UXD) on soil surface; A) water extractable organic carbon, WEOC, B) Water extractable nitrogen, WEN, C) water extractable phosphorus, WEP, D) NO3-N, and E) NH4-N.

fluctuations of those analytes in the 0 - to 10 -cm depth, although the general pattern of fluctuations of analytes at $10-20 \mathrm{~cm}$ followed the general pattern of fluctuation of the analytes in the 0 - to 10 -cmdepth. At the 10 to 20-cm depth, soil analyte content did not differ among the ND, XD, and UXD treatments (see Fig. 4), which indicated that the vertical translocation of nutrients from dung into the soil underneath was likely limited 
within the 0 - to 10 -cm depth. Therefore, discussion about the change of soil analytes is focused on the top 10-cm soil depth.

Soil WEOC of the ND control at $10-\mathrm{cm}$ depth temporarily peaked at 7 DAPs and returned to its initial value; the WEOC at 1 DAP (117 \pm 10 $\left.\mathrm{ug} \mathrm{g}^{-1}\right)$ and at 56 DAPs $\left(111 \pm 10 \mathrm{ug} \mathrm{g}^{-1}\right)$ did not differ. Dung treatments (XD or UXD) resulted in greater soil WEOC than the ND control. The LSmeans ( $n=192$, averaged over 2 yr, 2 seasons, 6 DAP, 8 replications) of soil WEOC content of the XD and UXD treatments was $172 \pm 5$ and $158 \pm 5$ ug g $^{-1}$, respectively. The peak differences among all treatments occurred at 14 DAPs (see Fig. 4A). At 14 DAPs, the LSmeans ( $n=32$, averaged over 2 yr, 2 seasons, 8 replications) of soil WEOC content of the XD treatment was $33 \pm 13 \mathrm{ug} \mathrm{g}^{-1}$ higher than that of the UXD treatment.

Soil WEN content of the ND control at the top 10-cm depth temporarily fluctuated, and the LSmeans ( $n=32$, averaged over 2 yr, 2 seasons, 8 replications) of WEN at 1 DAP ( $\left.40 \pm 3 \mathrm{ug} \mathrm{g}^{-1}\right)$ was higher than that at 56 DAPs (30 \pm 3 ). Dung treatments (XD and UXD) had greater soil WEN than the ND control. The LSmeans ( $n=192)$ of soil WEN content was higher in the XD ( $\left.49 \pm 1 \mathrm{ug} \mathrm{N} \mathrm{g}^{-1}\right)$ than that of the UXD treatments $\left(43 \pm 1 \mathrm{ug} \mathrm{g}^{-1}\right)$. The peak differences among all treatments occurred at 14 DAP (Fig. 4B). At 14 DAPs the LSmeans $(n=32)$ of soil WEN content in the XD treatment was $12 \pm 3 \mathrm{ug} \mathrm{N} \mathrm{g}^{-1}$ higher than that of the UXD treatment.

Soil WEP content of the ND control at $10-\mathrm{cm}$ depth temporarily peaked at 3 DAPs (see Fig. 4C) and then returned to initial value. Soil WEP content of the ND control at 1 DAP $\left(3.1+0.6 \mathrm{ug} \mathrm{g}^{-1}\right)$ and 56 DAPs $\left(2.3+0.6\right.$ ug g $\left.^{-1}\right)$ did not differ. Dung treatments (XD and UXD) had greater WEP than the ND control; the LSMeans $(n=192)$ of soil WEP content in the XD and UXD treatment was $7.5 \pm 0.3$ and $6.4 \pm 0.3$, respectively. The WEP content of soil under dung was $3.8 \pm 0.3 \mathrm{ug} \mathrm{P} \mathrm{g}^{-1}$ higher than that of the control. The peak differences among all treatments occurred at 14 DAP (see Fig. 4C). At 14 DAPs, the LSmeans $(n=32)$ of soil WEP content was $2.8 \pm 0.8 \mathrm{ug} \mathrm{P} \mathrm{g}^{-1}$ higher in the XD than UXD treatment.

Fluctuation of soil $\mathrm{NO}_{3}$ content of the ND treatment at top $10-\mathrm{cm}$ depth (Fig. 4D) was transient as the $\mathrm{NO}_{3}-\mathrm{N}$ at 1 DAP (15 $\left.\pm 2 \mathrm{ug} \mathrm{N} \mathrm{g}^{-1}\right)$ and 56 DAPs ( $11 \pm 2$ ug $\mathrm{N} \mathrm{g}^{-1}$ ) did not differ. The $\mathrm{NO}_{3}$ content of soil beneath the dung was $3.8 \pm 0.7 \mathrm{ug} \mathrm{N} \mathrm{g}{ }^{-1}$ higher than that of the control. The LSmeans $(n=192)$ of $\mathrm{NO}_{3}$ content was higher in the XD $\left(17 \pm 0.7 \mathrm{ug} \mathrm{N} \mathrm{g}^{-1}\right)$ than UXD $\left(4 \pm 0.7 \mathrm{ug} \mathrm{N} \mathrm{g}{ }^{-1}\right)$ treatment. The peak differences among all treatments 
occurred at 14 DAPs (see Fig. 4D). At 14 DAPs, the LSmeans $(n=32)$ of soil $\mathrm{NO}_{3}$ was $7 \pm 2 \mathrm{ug} \mathrm{N} \mathrm{g}^{-1}$ higher in the XD than UXD treatment.

The peak of $\mathrm{NH}_{4}$ content of the ND control at top 10-cm depth at 7 DAPs was short lived and returned to its initial value (see Fig. 4E) at 14 DAPs $\left(8 \pm 3 \mathrm{ug} \mathrm{N} \mathrm{g}{ }^{-1}\right)$ and remained constant through 56 DAPs ( $8 \pm 3$ ug $\mathrm{N} \mathrm{g}^{-1}$ ). The $\mathrm{NH}_{4}$ content of soil under the dung was $6.5 \pm 1.2 \mathrm{ug} \mathrm{N} \mathrm{g}^{-1}$ higher than that of the control. The LSmeans $(n=192)$ of soil $\mathrm{NH}_{4}$ content of the XD (18 $\pm 1 \mathrm{ug} \mathrm{N} \mathrm{g}^{-1}$ soil) was similar to that of the UXD treatment (18 \pm 1 ug $\mathrm{N} \mathrm{g}^{-1}$ soil). Lack of differences in $\mathrm{NH}_{4}$ content between the XD and UXD treatment indicated that dung beetles did not affect soil $\mathrm{NH}_{4}$ content.

\section{Horizontal Translocation of Dung Analytes}

Soils $30 \mathrm{~cm}$ away from the XD and UXD dung pats had similar content of all analytes (WEOC, WEN, WEP, $\mathrm{NO}_{3}-\mathrm{N}$, and $\mathrm{NH}_{4}-\mathrm{N}$ ) compared with those of the soil from the ND control for both the 0 - to $10-\mathrm{cm}$ and 10 to 20-cmsoil depths. There was not enough evidence to indicate a horizontal translocation of dung analytes to a distance of $30 \mathrm{~cm}$ away from the dung pat.

\section{Discussion}

\section{Change in Dung Physical and Chemical Properties}

The pattern of dung moisture loss in both the XD and UXD treatments fitted a three-parameter exponential decay function (see Fig. 2A). The pattern indicated a rapid dung moisture loss rate within the first week after dung application because of rapid moisture evaporation and moisture translocation into soil. The rate of dung moisture loss declined thereafter because of a lower evaporative rate as the dung became drier. Rapid drying produced a thin layer of dry crustlike material over the dung pat early after placement. Unfortunately, to our knowledge, no study has measured the physical properties of dung-crust layer. A crustlike layer, such as soil crusting, commonly has lower air permeability and low hydraulic conductivity (Radcliffe and Rassmussen, 2000; Nciizah and Wakindiki, 2015; Wang et al., 2015); the less permeable crust functions as a barrier for gas/vapor transport. 
Dung moisture in the XD was less than that of the UXD treatment because of a faster rate of moisture loss rate in the XD treatment within the first 7 DAPs. The half-life $\left(t_{0.5}\right)$ of dung moisture (the length of time to reach 50\% moisture left) in the XD and UXD treatments was 6.5 and $9.5 \mathrm{~d}$ after dung pat application, respectively. Rapid dung moisture loss of dung within 7 DAP is comparable with $50 \%$ loss observed by Lovell and Jarvis (1996). The 3-d faster moisture loss in the XD than UXD treatment was due to dung beetle activity. Lower dung moisture in the XD than UXD treatment during the first 7 DAP was concurrent with higher frequency and count of beetles. Dung beetles feed on dung liquid contents and cause a higher evaporation rate. Making passageways into or out of the dung pat, beetles leave macropores (e.g., tunnels) in the dung, which facilitate gas and vapor transport into and out of the dung to the atmosphere, bypassing the less permeable drycrust layer. Less than 0.3 $\mathrm{cm}$ of total rainfall occurred during the first $7 \mathrm{~d}$ after dung application in June or July of 2014. Total rainfall during the first $7 \mathrm{~d}$ after dung application in June and July of 2015 was $5 \mathrm{~cm}$ and $2 \mathrm{~cm}$, respectively. We estimate $1 \mathrm{~mm}$ rainfall (entered and remained in a dung pat surface area of $300 \mathrm{~cm}^{2}$ and DM of $300 \mathrm{~g}$ ) increased approximately $10 \%$ in dung moisture content. More water infiltration due to dung-made macropores in the XD treatment would increase moisture loss rate in the XD than UXD treatment.

Losses of dung DM from dung pats (XD and UXD treatments) can be attributed to gaseous losses of dung $\mathrm{C}$ and $\mathrm{N}$ and leaching of dung dissolved nutrients (see Table 4) and minerals such as soluble salts. In the XD treatment, a dung DM loss of 21\% (58 $\mathrm{g} \mathrm{DM}$ pat $^{-1}$ ) within 56 DAP was equivalent to a loss of $1 \mathrm{~g} \mathrm{DM} \mathrm{d}^{-1}$ pat $^{-1}$ or $\approx 0.4 \mathrm{~g} \mathrm{C} \mathrm{d}^{-1}$ pat $^{-1}$ (based on dung DM organic-C content of $38 \%$ ). Our measurement of $\mathrm{CO}_{2}$ gas efflux from the XD treatment (mixture of gas efflux from dung and its interaction with the soil underneath the dung) on the same sites was 0.2 $\mathrm{g} \mathrm{C} \mathrm{d}^{-1}$ pat $^{-1}$. Assuming that $50 \%$ of $\mathrm{CO}_{2}$ efflux $\left(0.1 \mathrm{~g} \mathrm{C} \mathrm{d}^{-1}\right.$ pat $\left.^{-1}\right)$ was from the dung pat alone, it was suggested that $25 \%$ of dung DM loss was as $\mathrm{CO}_{2}$-C efflux. This estimate illustrated that microbial oxidation of dung DM was an important process of dung DM loss. Yoshitake et al. (2014) observed a loss of $71 \%$ of dung $\mathrm{C}$ due to aerobic decomposition within a single grazing period.

The LSmeans $(n=192)$ of dung DM in the XD treatment was 2.8\% less than that in the UXD treatment, especially during the first 7 DAPs, which is likely explained by the high frequency and counts of dung beetles. 
Dung beetle contribution to dung DM loss was by consumption of dissolved nutrients of wet dung and processes associated with macropores. In another study, the companion to this study, it was found that $\mathrm{CO}_{2}$ efflux from the XD treatment was $70 \mathrm{mg} \mathrm{C} \mathrm{d}^{-1}$ pat $^{-1}$ higher than that in the UXD treatment. We presume other soil fauna and dung beetle activity allowed more gas transport, infiltration of rainfall water, and thus promoted microbial activity and dung decomposition. This observation was similar to that of Dickinson et al. (1981) in which crust prevented rewetting of dung and thus slowed DM loss.

Dung DM relations with length of time after dung application indicated a slow dung decomposition rate of $0.2 \%$ and lower at $30 \mathrm{~d}$ and later after dung application, when dung was in a desiccated state and dung beetles were absent. The equations of exponential decay function of dung DM in the XD treatment (Fig. 2B) also indicated that even with exposure to soil fauna, the length of time to reach $25 \%$ loss of dung DM is longer than the 5-mo growing season. In this temperate region freezing and thawing cycles during winter may facilitate the breaking of dung pats into smaller chunks and enable faster degradation in the next spring and summer; however, this is beyond the scope of our study.

Rapid decrease in dung content of WEOC (25\%), WEN (42\%), WEP (46\%), and $\mathrm{NH}_{4}-\mathrm{N}(65 \%)$ occurred within the first 14 DAPs. At 56 DAPs, the LSmeans of mass loss of dung WEOC, WEN, WEP, and NH4- N in the UXD treatment (see Table 1) was 41\%, 70\%, 62\%, and 56\%, respectively. Dickinson et al. (1981) associated marked loss of $\mathrm{C}$ with losses of soluble carbohydrate. The WEN and $\mathrm{NH}_{4}$ losses in our study were much larger than the $8 \%$ of dung $\mathrm{N}$ loss within the first $20 \mathrm{~d}$ reported by Dickinson et al. (1981). No significant difference in content or mass loss of these analytes between the XD and the UXD treatments indicated that soil faunas had no observable effects on changes of dung chemical analytes.

\section{Translocation of Dung Derived Analytes}

Soil WEOC, WEN,WEP, and $\mathrm{NH}_{4}-\mathrm{N}$ analytes peaked within the first 14 DAPs for the XD, UXD, and ND controls. The transient peak of these soil analytes in the ND control treatment indicated contribution of mineralization of existing soil organic matter and nutrients from decomposition of grass litter in increasing soil analytes in the top 10-cm depth. Nutrients from grass litter presumably are from dissolved, nonstructural compound of litter leaching into the top soil. A study by Cotrufo et al. (2015) 
indicated that one third of carbon loss and high rate of N loss of Andropogon gerardii grass litter was from nonstructural material during the early stage of decomposition, which resulted in increased soil organic carbon. In our study, together with the litter dissolved organic $\mathrm{C}, \mathrm{N}$, and $\mathrm{P}$, translocated dissolved $\mathrm{C}, \mathrm{N}$, and $\mathrm{P}$ from dung onto the grass layer resulted in an additional pool of dissolved organic $\mathrm{C}, \mathrm{N}$, and $\mathrm{P}$ above the soil. The larger pool of dissolved $\mathrm{C}, \mathrm{N}$, and $\mathrm{P}$ of the dung treatments resulted in transient and higher soil WEOC, WEN, WEP, and $\mathrm{NH}_{4}-\mathrm{N}$ contents than those in the ND control in the top $10 \mathrm{~cm}$ of soil (see Fig. 4).

While mass loss of dung C, N, P and thus additional C, N, P pool above the soil was measurable, in this study there were other processes that likely contributed to the differences between dung treatments and the ND control (i.e., the physical and biochemical processes in the interfacial contact zone). The interfacial zone is a zone where there are interactions or contacts of the bottom of the dung pat, grass litter, and soil top layer. The importance of the interfacial contact zone in our study was based on the fact that the timing and magnitude of rapid losses of dung analytes were followed by the rapid rise of analytes in the top soil within a short time (within the first 7-14 DAPs).

The processes in the interfacial zone contributed to the rapid dung water loss in the first 7 DAPs. The loss of $50 \%$ of initial dung moisture was approximately equivalent to $5 \mathrm{~mm}$ of water loss. Water seepage from very wet dung pats (DM-based initial moisture of 460\%) carried soluble $\mathrm{C}, \mathrm{N}$, and $\mathrm{P}$ into the interfacial zone on placement of dung pats on the grassed soil surface. It was likely that wetting and enrichment (with soluble analyte) of the interfacial contact zone functioned as a primer for microbial activity and growth of microbial biomass in the zone. Furthermore, as the crust over the dung surface slowly formed, vapor movement from dung and soil likely kept the interfacial contact zone relatively moist, promoting microbial activity. Wachendorf and Joergensen (2011) found 16-45\% greater microbial biomass C and 24-57\% greater microbial biomass $\mathrm{N}$ under dung pats than that in untreated soil. Bloor (2015) reported that dung addition had a positive effect on soil inorganic $\mathrm{N}$, dissolved organic $\mathrm{C}$, and total soil $\mathrm{C}$ and $\mathrm{N}$ content under dung pats after 4 mo. Lovell and Jarvis (1996) observed increased concentrations of soil inorganic $\mathrm{N}$ in response to dung addition. Placement of dung on a grass litter layer also blocked light and slowed grass growth and nutrient uptake. Perhaps seepage of soluble salt from dung pats also resulted in grass-leaf burn, temporarily reducing plant growth. The higher 
analyte content of soil under dung pats is likely explained by the combination of these factors.

Mass loss of dung analytes entering into the interfacial contact zone from dung pat in the XD and UXD treatments was similar, yet soil analytes were higher in the XD than UXD treatment, which explains the effect of exposing dung pat to soil fauna, such as the dung beetle. We speculate that dwelling beetle macropores enhanced transport of water, gas, and vapor, resulting in enhanced physical and biochemical processes in the interfacial contact zone. Holter (1979) reported that activity of dung beetles and their larvae accelerated aggregation of earthworms under dung pats. Other processes of how exposed dung treatment resulted in increased soil analytes could not be substantiated.

Soil analyte content at 10 - to 20 -cm depth among all treatments was similar at all DAPs. Transient peak of soil analytes at $10-20 \mathrm{~cm}$ in the XD, UXD, and ND control treatments indicated a contribution of mineralization of existing soil organic matter, which is commonly influenced by soil moisture and temperature. The mineralization of soil organic matter resulted in a similar pattern of soil analyte fluctuation at the 10to $20-\mathrm{cm}$ and 0 - to $10-\mathrm{cm}$ depth (see Fig. 4). There was not enough evidence to suggest that dung nutrients were translocated deeper than 10-cm depth. Yoshitake et al. (2014) observed herbage growth at the edge of dung pats due to plant uptake of dung-derived $\mathrm{NH}_{4}$ andNO $\mathrm{N}_{3}$. Besides plant uptake, perhaps, the 56 DAPs were not enough time to allow deeper translocation.

\section{Implications}

Soil fauna, as indicated by dung beetles, accelerated losses of dung pat moisture and DM. While exposing dung pats to dung beetles affected dung physical properties, the exposure did not affect the content and loss of dung WEOC, WEN, WEP, and $\mathrm{NH}_{4}-\mathrm{N}$. Most of these dung analyte losses (exposed or not exposed to soil fauna) occurred within 7 DAPs, and these analytes were translocated vertically into underneath soils. Dung beetles increased soil WEOC, WEN, WEP, and $\mathrm{NO}_{3}-\mathrm{N}$ at 0 - to $10-\mathrm{cm}$ depth. There was not enough evidence to suggest that dung nutrients were translocated into the soil deeper than 10-cm depth. Our study suggested that dung beetles accelerated dung decomposition and increased soil nutrient in the top 0 to $10-\mathrm{cm}$ depth of rangeland sandy soils. 
Acknowledgments - The authors thank Pamela Sutton, Jonathan Soper, Erin Hatch, Jenna Beckman, Matt Judkins, Jake Siel, Julia Franck, Julio Rangel, and Samantha Teten for field and laboratory assistance.

\section{References}

Aarons, S.R., Hosseini, H.M., Dorling, L., Gourley, C.J.P., 2004. Dung decomposition in temperate dairy pastures. II. Contribution to plant-available soil phosphorus. Soil Research 42 (1), 115-123.

Anderson, J.R., Merritt, R.W., Loomis, E.C., 1984. The insect-free cattle dropping and its relationship to increased dung fouling of rangeland pastures. Journal of Economic Entomology 77 (1), 133-141.

Bang, H.S., Lee, J., Kwon, O.S., Na, Y.E., Jang, Y.S., Kim, W.H., 2005. Effects of paracoprid dung beetles (Coleoptera: Scarabaeidae) on the growth of pasture herbage and on the underlying soil. Applied Soil Ecology 29 (2), 165-171.

Bertone, M.A., 2004. Dung beetles (Coleoptera: Scarabaeidae and Geotrupidae) of North Carolina cattle pastures and their implications for pasture improvement [thesis]. North Carolina State University, Raleigh, NC, USA, p. 174.

Bloor, J.M.G., 2015. Additive effects of dung amendment and plant species identity on soil processes and soil inorganic nitrogen in grass monocultures. Plant and Soil 396, 189-200.

Breymeyer, A., Zacharieva-Stoilova, B., 1975. Scarabaeidae in two mountain pastures in Poland and Bulgaria. Serie des Sciences Biologiques Bulletin.

Calderón, F.J., McCarty, G.W., Van Kessel, J.A.S., Reeves, J.B., 2004. Carbon and nitrogen dynamics during incubation of manured soil. Soil Science Society of America Journal 68 (5), 1592-1599.

Cotrufo, M., Francesca, J., Soong, L., Horton, A.J., Campbell, E.E., Haddix, M.L., Wall, D.H., Parton, W.J., 2015. Formation of soil organic matter via biochemical and physical pathways of litter mass loss. Nature Geoscience 8, 776-779.

Dickinson, C.H., Underhay, V.S.H., Ross, V., 1981. Effect of season, soil fauna and water content on the decomposition of cattle dung pats. New Phytology 88, 129-141.

Doube, B., 1991. Dung beetles of southern Africa. In: Hanski, I., Cambefort, Y. (Eds.), Dung beetle ecology. Princeton University Press, Princeton, NJ, USA, pp. 133-155.

Errouissi, F.F., Haloti, S., Jay-Robert, P., Janati-Idrissi, A., Lumaret, J.P., 2004. Effects of the attractiveness for dung beetles of dung pat origin and size along a climatic gradient. Environmental Entomology 33, 4553.

Fincher, G.T., 1981. The potential value of dung beetles in pasture ecosystems. Journal of Georgia Entomological Society 16 (Suppl. 1), 316-333.

Finn, J.A., Giller, P.S., 2000. Patch size and colonisation patterns: an experimental analysis using north temperate coprophagous dung beetles. Ecography 23, 315-327.

Freymann, B.P., Buitenwerf, R., Desouza, O., Olff, H., 2008. The importance of termites (Isoptera) for the recycling of herbivore dung in tropical ecosystems: a review. European Journal of Entomology 105 (2), 165. 
Halffter, G., Edmonds, W.D., 1982. The nesting behavior of dung beetles (Scarabaeinae). An ecological and evolutive approach. Instituto de Biologia, Mexico D.F. 176 pages.

Holter, P., 1979. Effect of dung beetles (Aphodius spp.) and earthworms on the disappearance of cattle dung. Oikos 33 (3), 393-402.

Holter, P., 1982. Resource utilization and local coexistence in a guild of Scarabaeid dung beetles (Aphodius spp.). Oikos 39, 213-227.

Lee, C.M., Wall, R., 2006. Cow-dung colonization and decomposition following insect exclusion. Bulletin of Entomological Research 96, 315-322.

Little, R.C., Milliken, G.A., Stroup, W.W., Wolfinger, R.D., 1996. SAS system for mixed models. SAS Institute, Cary, NC, USA.

Lovell, R.D., Jarvis, S.C., 1996. Effect of cattle dung on soil microbial biomass C and N in a permanent pasture soil. Soil Biology and Biochemistry 28, 291-299.

Lund, H.G., 2007. Accounting for the world's rangelands. Rangelands 29 (1), 3-10.

MacDiarmid, B.N., Watkin, B.R., 1972. The cattle dung patch. Grass and Forage Science 27 (1), 43-47.

Mittal, I.C., 1993. Natural manuring and soil conditioning by dung beetles. Tropical Ecology 34 (2), 150-159.

Murphy, J., Riley, J., 1962. A modified single solution method for the determination of phosphate in natural waters. Analytica Chimica Acta 27, 31-36.

Nciizah, A.A., Wakindiki, I.C., 2015. Soil sealing and crusting effects on infiltration rate: a critical review of shortfalls in prediction models and solutions. Archives of Agronomy and Soil Science 61 (9), 1211-1230.

Nichols, E.E., Spector, S.S., Louzada, J.J., Larsen, T.T., Amezquita, S.S., Favila, M.E., 2008. Ecological functions and ecosystem services provided by Scarabaeinae dung beetles. Biological Conservation 141, 1461-1474.

O'Hea, N.M., Kirwan, L., Finn, J.A., 2010. Experimental mixtures of dung fauna affect dung decomposition through complex effects of species interactions. Oikos 119 (7), 1081-1088.

Pecenka, J.R., Lundgren, J.G., 2018. The importance of dung beetles and arthropod communities on degradation of cattle dung pats in eastern South Dakota. Peer Journal 6, e5220.

Pentillä, A., Slade, E.M., Simojoki, A., Riutta, T., Minkinnen, K., Roslin, T., 2013. Quantifying beetle-mediated effects on gas fluxes from dung pats. PLoS One 8 (8), $1-7$.

Piccini, I., Arnieri, F., Caprio, E., Nervo, B., Pelissetti, S., Palestrini, C., Roslin, T., Rolando, A., 2015. Greenhouse gas emissions from dung pats vary with dung beetle species and with assemblage composition. PLoS One 12 (7), e0178077.

Radcliffe, D.E., Rassmussen, T.C., 2000. Soil water movement. In: Sumner, M.E. (Ed.), Handbook of soil science, p. A-103.

Ratcliffe, B.C., Paulsen, M.J., 2008. The Scarabaeoid beetles of Nebraska. Bulletin of the University of Nebraska State Museum 22, 1-57.

Ružicka, J., Hansen, E.H., 1988. Flow injection analysis. vol. 62. John Wiley \& Sons, New York, NY, USA, p. 528. 
SAS Institute, 2014. SAS/STAT 13.2 User's guide. Version 9.4. SAS Institute, Cary, NC, USA, p. 673.

Stevenson, B.G., Dindal, D.L., 1987. Insect effects on decomposition of cow dung in microcosms. Pedobiologia 30, 81-92.

Strong, L., 1992. Avermectins: a review of their impact on insects of cattle dung. Bulletin of Entomological Research 82, 265-274.

Suarez, V.H., Lifschitz, A.L., Sallovitz, J.M., Lanusse, C.E., 2003. Effects of ivermectin and doramectin faecal residues on the invertebrate colonization of cattle dung. Journal of Applied Entomology 127, 481-488.

Underhay, V.H.S., Dickinson, C.H., 1978. Water, mineral and energy fluctuations in decomposing cattle dung pats. Grass and Forage Science 33 (3), 189-196.

Van Kessel, J.S., Reeves, J.B., Meisinger, J.J., 2000. Nitrogen and carbon mineralization of potential manure components. Journal of Environmental Quality 29 (5), 1669-1677.

Wachendorf, C., Joergensen, R.G., 2011. Mid-term tracing of ${ }^{15} \mathrm{~N}$ derived urine and dung in soil microbial biomass. Biology and Fertility of Soils 47, 147-155.

Wagner, M.W., 2016. Influence of cattle grazing practices on dung beetle (Coleoptera: Scarabaeoidea) communities in the Sandhill rangelands of Central Nebraska [MS thesis]. Department of Entomology. University of Nebraska, Lincoln, NE, USA Available at: https://digitalcommons.unl.edu/entomologydiss/43/ Accessed date: 14 January 2019.

Wang, W.-H., Jian-Bo, L., Xiang-Bo, W., 2015. Effects of biological soil crusts on soil air permeability and water conductivity. Journal of Drainage and Irrigation Machinery Engineering 33 (8), 701-707.

Whipple, S.D., 2011. Dung beetle ecology: habitat and food preference, hypoxia tolerance, and genetic variation [PhD dissertation]. University of NebraskaLincoln, Lincoln, NE, USA, p. 132. https://digitalcommons.unl.edu/ entomologydiss/12/

Whisenant, S.G., 1999. Repairing damaged wildlands: a process-orientated, landscape-scale approach. Cambridge University Press, New York, NY, USA, p. 312.

Yokoyama, K., Kai, H., Koga, T., Aibe, T., 1991. Nitrogen mineralization and microbial populations in cow dung, dung balls, and underlying soil affected by paracoprid dung beetles. Soil Biology and Biochemistry 23 (7), 649-653.

Yoshitake, S., Soutome, H., Koizumi, H., 2014. Deposition and decomposition of cattle dung and its impact on soil properties and plant growth in a cool-temperate pasture. Ecological Research 29, 673-684. 